\title{
Shotguns and sustainable hunting in the Neotropics
}

\author{
M. Alvard
}

The shift to the use of shotguns from traditional hunting weapons has often been mentioned as one of the factors contributing to over-hunting in the tropics. It has also been argued that indigenous people using traditional hunting methods are conservationists because they do not over-exploit natural resources. A study of two Indian communities in south-eastern Peru, one of which hunted with guns and the other with traditional weapons, found that there was little difference in the amount of meat consumed per capita in each village and that shotgun hunters were no more exploitative than the traditional hunters.

\section{Introduction}

Two schools of thought are emerging from the debate over the role indigenous people can can expect to take in the effort to conserve biodiversity (e.g. Alcorn, 1993; Redford and Stearman, 1993). One school might be described as believing that the commitment of indigenous people to conservation is complex and very old' (Alcorn, 1993, p. 425; also Posey, 1985; Clay, 1988; Bunyard, 1989). The second view is that indigenous people are no different from the rest of humanity. Their activities reflect a short-term interest in their own welfare and that of their families; they are expected to over-exploit their environment if that is what is required to meet those goals (Redford, 1991; Hames, 1987, 1991; Alvard, 1993a, b, 1994).

The disparity has arisen for a number of reasons, perhaps related to how 'conservation' is defined (Alvard, 1993b; Redford and Stearman, 1993). It has been argued that it is an error to conclude that indigenous groups are conservationists simply because they are not over-exploiting their resources. True conservation must involve paying a short-term cost in anticipation of long-term benefits (Alvard, 1993b, 1994). Many indigenous groups use resources in sustainable ways only because they do not possess the ability to cause serious environmental degradation, rather than because they limit what they acquire.
This is changing, however. Many indigenous groups are undergoing rapid transformations, with some communities moving from a Neolithic way of life to a post-modern one in less than a generation; the Yanomamo of Brazil and Venezuela are a timely example (Chagnon, 1993). Larger and more dense settlements, and access to markets where meat can be sold create a situation where native groups, who in the past may not have overhunted, now have the ability to easily deplete their prey.

One vector of change that is often cited as particularly important in this regard is technological change, and the use of shotguns is often mentioned as one of the major factors contributing to over-hunting (Mittermeier, 1987). Although traditional hunting technology, such as bows, blowguns and spears, are effective, indigenous groups often adopt shotgun technology as it becomes available from outside groups. While there is no doubt that shotguns are more productive hunting weapons, their effect on the sustainability of indigenous hunting has not yet been fully evaluated in the context of other changes (see, however, Hames, 1979; Yost and Kelly, 1983; Redford and Robinson, 1987).

Below the hunting yields of two native Neotropical communities are compared: one group are bow-hunters, the other group primarily shotgun-hunters. The aim of this paper 


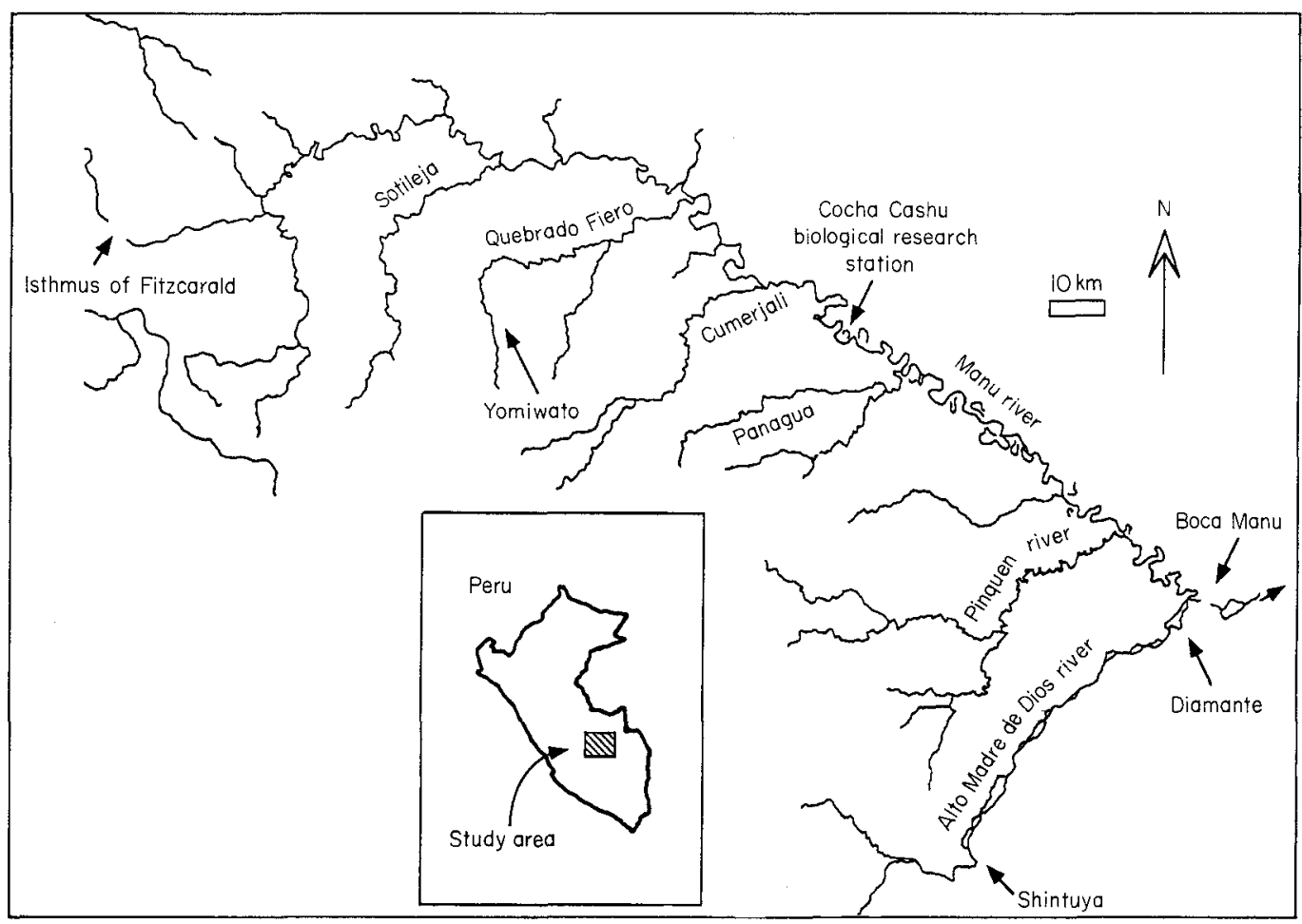

Figure 1. Map of the Manú area. Manú National Park encompasses the entire watershed of the Manú River. Yomiwato is located on the Quebrado Fiero tributary of the Manú River. Diamante is located on the Madre de Dios River, which is the south-east border of the Manú Biosphere reserve zone.

is to show that the adoption of shotguns does not necessarily lead to larger harvests. It will be demonstrated that there is little difference in the size of the per capita harvest in the two study villages, as would be expected if the shotgun hunters were using their increased killing power to harvest more meat. While the total harvest is larger for shotgun hunters compared with bow-hunters, it is directly proportional to the larger population size of their village. However, this result is consistent with the conclusion that indigenous people are quite capable of over-exploiting their environment, given the capacity and incentive.

\section{The study site and the two indigenous communities}

Research was initiated in 1988 to study the hunting activities of two communities of
Neotropical hunter-horticulturalists: the Piro and the Machiguenga. The two groups live in the tropical rain forests of south-eastern Peru in and around Manú National Park (Figure 1). The park encompasses more than $15,000 \mathrm{sq}$ $\mathrm{km}$ and covers nearly the entire drainage of the Manú River.

The Piro and Machiguenga differ in a number of important ways (Table 1; also see Alvard and Kaplan, 1991; Alvard, 1993a, b, 1994, for more details) Approximately 100 Machiguenga live in the village of Yomiwato, which is located inside Manú Park on a small tributary of the Manú River. The Yomiwato economy is entirely subsistence based. Cultivation of manioc and plantains supplies the bulk (70 per cent) of the calories consumed. Hunting and fishing with bow and arrow, and hook and line provide most of the protein and fat in their diet. Within the boundaries of the park all extractive commercial 
Table 1. Contrasts between the Piro village of Diamante and the Machiguenga village of Yomiwato

\begin{tabular}{ll}
\hline Diamante & Yomiwato \\
\hline Larger population: 250 & Smaller population: 100 \\
Rapid population growth rate: $4.7 \%$ & Slow population growth rate: $1.2 \%$ \\
Shotgun technology & Bow technology \\
Outside Manu National Park, floodplain lowlands & Inside Manú National Park, interior uplands \\
\hline
\end{tabular}

Table 2. Mammals and birds encountered during hunts by Machiguenga and Piro hunters. Species that contributed more than 3 per cent to the total harvest by weight in either village are indicated by $\sqrt{ }$; those that were pursued but contributed less than 3 per cent of the harvest are indicated by *; those that were never observed pursued for meat are indicated by -. For a more detailed discussion of Piro prey choice see Alvard (1993b)

\begin{tabular}{|c|c|c|c|}
\hline Animal type & Scientific name & English name & $>3 \%$ of harvest \\
\hline \multirow[t]{5}{*}{ Ungulates } & Tapirus terrestris & Brazilian tapir & $\sqrt{ }$ \\
\hline & Mazama americana & Red brocket deer & $\sqrt{ }$ \\
\hline & M. gouazoubira & Grey brocket deer & $*$ \\
\hline & Tayassu tajaca & Collared peccary & $\sqrt{ }$ \\
\hline & T. pecari & White-lipped peccary & * \\
\hline \multirow[t]{9}{*}{ Primates } & Lagothrix lagothricha & Woolly monkey & $\sqrt{ }$ \\
\hline & Ateles paniscus & Spider monkey & $\sqrt{ }$ \\
\hline & Alouatta seniculus & Howler monkey & $\sqrt{ }$ \\
\hline & Cebus apella & Brown capuchin monkey & * \\
\hline & C. albifrons & White capuchin monkey & * \\
\hline & Saimiri sciureus & Squirrel monkey & * \\
\hline & Callicebus moloch & Titi monkey & $*$ \\
\hline & Saguinus nigricollis & Black-mantled tamarin & * \\
\hline & Aotus spp. & Night monkey & * \\
\hline \multirow[t]{4}{*}{ Rodents } & Hydrochaeris hydrochaeris & Capybara & $\sqrt{ }$ \\
\hline & Agouti paca & Paca & $*$ \\
\hline & Dasyprocta variegata & Agouti & $*$ \\
\hline & Sciurus sp. & Squirrel & * \\
\hline \multirow[t]{4}{*}{ Edenata } & Priodontes maximus & Giant armadillo & $*$ \\
\hline & Dasypus novemcinctus & Armadillo & * \\
\hline & Tamandua tetradactyla & Collared anteater & - \\
\hline & Choloepus sp. & Two-toed sloth & - \\
\hline \multirow[t]{8}{*}{ Carnivores } & Panthera onca & Jaguar & - \\
\hline & Felis concolor & Puma & - \\
\hline & F. pardalis & Ocelot & - \\
\hline & Eira barbara & Tayra & - \\
\hline & Lutra longicaudis & Nutria & - \\
\hline & Pteronura brasilensis & Giant otter & - \\
\hline & Nasua nasua & Coati & $*$ \\
\hline & Atelacynus microtis & Short-eared dog & - \\
\hline \multirow[t]{3}{*}{ Birds (Cracidae) } & Penelope jacquacu & Spix's guan & * \\
\hline & Aburria pipile & Guan & $*$ \\
\hline & Mitu mitu & Currassow & * \\
\hline \multirow[t]{7}{*}{ Birds (others) } & Crypturellus spp. & Tinamous & * \\
\hline & Tinamus spp. & Tinamous & * \\
\hline & Ara spp. & Macaws & * \\
\hline & Ramphastos spp. & Toucan & * \\
\hline & Odontophorus spp. & Wood quail & * \\
\hline & Psophia leucoptera & Trumpeter & $*$ \\
\hline & Harpia harpyja & Harpy eagle & - \\
\hline
\end{tabular}


activities are prohibited, as is shotgun hunting. Hunting is strictly by traditional means, the bow being the primary hunting weapon. There is no market participation.

Ninety kilometres south-east of Yomiwato and just outside the Manú Biosphere reserve zone on the Alto Madre de Dios River, live more than 200 Piro in the village of Diamante. The Piro share the Machiguenga's reliance on horticulture, hunting and fishing to provide the bulk of their food. Approximately 7 per cent of the calories consumed in Diamante, however, were purchased commercial foods such as rice, flour, sugar and alcohol. The Piro of Diamante have had a longer history of contact with the outside world and, because they live outside the park, they have no restrictions on technology. The community owns a chainsaw and a 55-hp outboard boat motor; a number of families own small 16-hp motors for their dugout canoes, and seven men own shotguns, which in addition to traditional bows, are commonly used to hunt. While the Piro are very proficient bow hunters, 87 per cent of the meat by weight was harvested with shotguns during the study period. Market participation varies with the expansion and contraction of the local Peruvian economy. Some men occasionally work as boat drivers for river traders while others cut and sell lumber.

Inside Manú National Park, located about half-way between the two villages, is the biological research station of Cocha Cashu, where J. Terborgh and his students have been conducting ecological studies since the early 1970s (Terborgh, 1983). Many of the hundreds of species of birds and mammals recorded at Cocha Cashu are preyed upon by the Piro and Machiguenga, although only a few are important either in terms of numbers killed or in terms of their importance to the diet of the people. Table 2 lists mammal species that were encountered during observed hunts with the Piro and Machiguenga.

\section{Methods}

Data were collected during two field sessions in 1988-89 and 1990-91. A total of 16 months

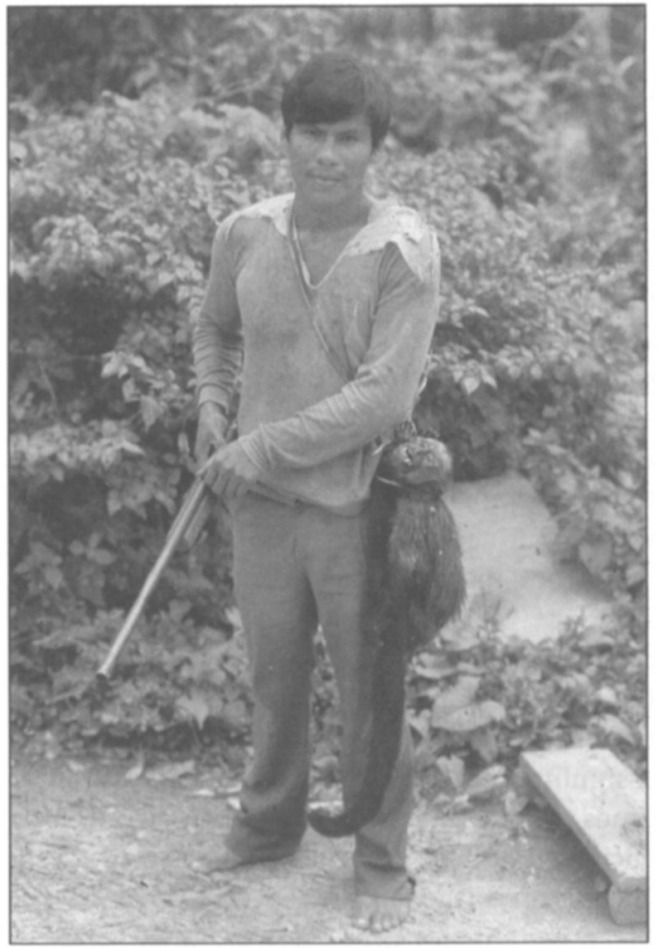

Piro hunter and shotgun. The monkey is a brown capuchin Cebus apella (Michael Alvard).

were spent with the Piro and 7 months with the Machiguenga. The author collected data from the Piro and $H$. Kaplan and $K$. Kopischke collected the Machiguenga data.

The data were collected using both interview and direct observation methods. To determine the per capita harvest, a sample of households in each community were visited every 3 days and interviews were conducted to determine all mammalian game killed since the last visit. The Piro and Machiguenga samples consisted of 116 and 85 consumers respectively. A consumer was defined as an individual over 3.5 years of age. For each consumer in the sample, the number of days present in the community were summed across the study period; the total number of days for each consumer was summed to determine the total number of consumer days sampled. A total of 37,003 consumer-days were observed for the Piro and 7133 for the Machiguenga. Each animal killed was multi- 
plied by the appropriate estimated weight for the species. The values were summed and divided by the total number of consumer-days observed to determine the grams per consumer harvested per day.

Ninety-five hunts were also directly observed - 16 for the Machiguenga and 79 for the Piro. Hunters were followed into the forest and their behaviour recorded and timed: travel, encounters with prey, pursuit of game, and kill. The following data were obtained for all animals killed: species, sex, age, reproductive status and weight. In addition, interviews were conducted with the Piro concerning hunts not directly observed. Interviews consisted of questions relating to the date, the participants and the location of the hunt. Because the Piro were familiar with western time-keeping and were remarkably good at assigning times by the position of the sun, times of departure and return were also elicited. Hunters were asked to list all game encountered, those pursued and those killed. Mean weights for prey were assigned, and return rates calculated. In total, 124 interviews were conducted with Piro hunters.

\section{The technology}

The greater productivity of shotguns compared with other weapons such as bows and blowguns has been demonstrated (Rambo, 1978; Hames 1979; Yost and Kelly 1983) and this is also true for this study (Table 3 ). The return rates (total undressed $\mathrm{kg}$ acquired divided by total hours hunted) for Piro shotgun hunts were uniformly high for all the samples, ranging between 1.17 and $1.5 \mathrm{~kg}$ per hour of hunting. The Machiguenga bow hunters obtained only $0.10 \mathrm{~kg} / \mathrm{h}$ during 16 observed hunts. Because of the small number of Machiguenga hunts observed, this 10-fold difference may be an over-estimate. Fifty-three unobserved, but reported, bow hunts in Diamante had a higher return rate of 0.38 $\mathrm{kg} / \mathrm{h}$. The mean return rates from the combined samples of 69 bow hunts and 146 shotgun hunts are $0.327 \mathrm{~kg} / \mathrm{h}$ and $1.37 \mathrm{~kg} / \mathrm{h}$, respectively. A Mann-Whitney $U$-test on the combined samples showed that this difference was statistically significant $(z=-3.735, n=215$, $P=0.0002$ ).

One reason shotguns are so much more effective is their ability to knock down and kill the prey. For the 1988-89 sample of observed hunts, Piro shotgun hunters averaged 1.3 shots per kill, while Machiguenga bow hunters averaged 30 shots (Alvard and Kaplan, 1991). Machiguenga bow pursuits are also significantly longer than Piro shotgun pursuits (Alvard and Kaplan, 1991). Arrows often miss their target or only wound the prey; shotguns frequently kill prey with a single shot.

\section{The harvest}

It was predicted that the Piro hunters would take advantage of the greater effectiveness of shotguns and harvest more meat than the Machiguenga hunters. That is, it was expected that the Piro's per capita harvest would be larger than the Machiguenga's. This, however,

Table 3. Return rates for Piro and Machiguenga hunts. Return rate is calculated by dividing the total amount of meat harvested (undressed) by the total number of hunter-hours

\begin{tabular}{|c|c|c|c|c|}
\hline Sample & $n$ & $\begin{array}{l}\text { Harvested weight } \\
\text { (undressed) } \\
\text { (kg) }\end{array}$ & Hunter-hours & $\begin{array}{l}\text { Return rate } \\
(\mathrm{kg} / \mathrm{h})\end{array}$ \\
\hline Piro, 1988-89, observed shotgun hunts & 27 & 291.00 & 243.25 & 1.20 \\
\hline Piro, 1990-91, observed shotgun hunts & 48 & 517.90 & 344.15 & 1.50 \\
\hline Piro, unobserved shotgun hunts & 71 & 698.70 & 595.40 & 1.17 \\
\hline Piro, unobserved bow hunts & 53 & 233.69 & 606.07 & 0.38 \\
\hline Machiguenga, observed bow hunts & 16 & 24.35 & 231.40 & 0.10 \\
\hline
\end{tabular}


is not the case: the amount of meat harvested per consumer per day was very similar in the two communities (Figure 2). For the Piro, 223 and $282 \mathrm{~g}$ per consumer-day were harvested in 1988-89 and 1990-91, respectively, for a weighted mean of $247 \mathrm{~g}$ per consumer-day; $244 \mathrm{~g}$ per consumer-day were harvested by the Machiguenga in 1988-89.

To determine the amount of meat sold by the Piro, interviews with the 28 hunters in the consumer sample were conducted in 1990-91. The interviews, representing 714 consumerdays, indicated that an average of $0.15 \mathrm{~kg}$ of game were sold per hunter per day, mainly to river traders supplying gold mines down river. This amounts to $4.24 \mathrm{~kg}$ for the sample per day or about $0.036 \mathrm{~kg}$ per consumer-day. Subtracting this amount sold from the per capita harvest in 1990-91, reduces the amount remaining in the village to $246 \mathrm{~g}$ per consumer-day at Diamante for that year.

It should be noted that each group obtained similar quantities of fish, the other primary source of protein and fat. Approximately $283 \mathrm{~g}$ and $313 \mathrm{~g}$ per consumer per day were harvested by the Machiguenga and the Piro, respectively in 1989-90 (Kaplan et al., 1990).

In spite of the fact that shotguns are more than four times as productive as bows, the average Piro did not consume more meat than did the average Machiguenga. This agrees with findings of Harner (1968), Vickers (1976) and Hames (1979), who worked with other Neotropical groups and report that, although shotguns are more efficient hunting weapons, the total amount of meat harvested with shotguns is not proportionally greater than the amount harvested with bows or blowguns.

This result has interesting corollaries. The first is that Piro hunters could easily obtain more meat per person, but do not. Apparently, increasing the harvest beyond a certain point has diminishing returns to Piro hunters. It is easy to imagine that the nutritional benefits, for example, from meat decline beyond a certain quantity, especially if there are opportunity costs involved in hunting. The same pattern is suggested with regard to hunting to obtain meat for sale. While approximately 13 per cent of the Piro harvest was sold outside

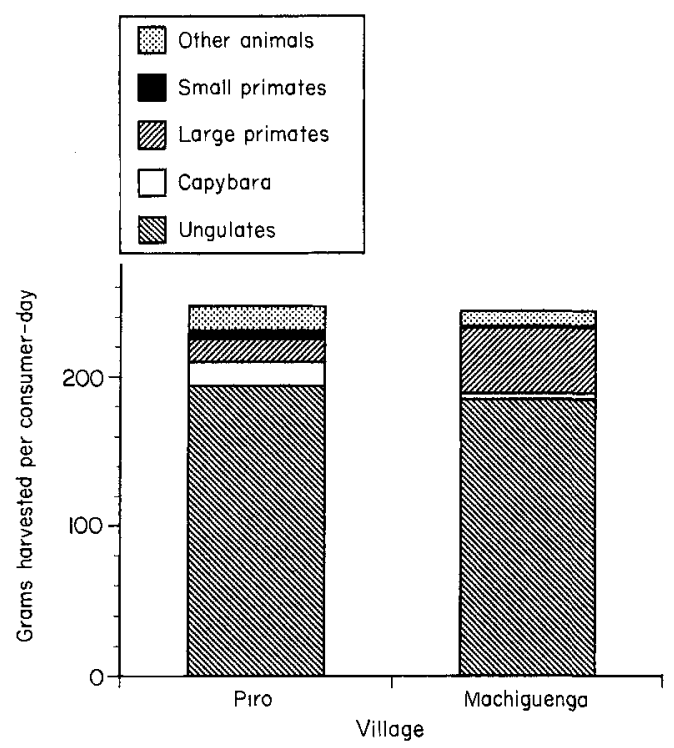

Figure 2. A comparison of the total biomass harvested per consumer-day in the Piro village of Diamante and the Machiguenga village of Yomiwato. A consumer is an individual over 3.5 years of age. Number of observed consumer-days: Diamante, 37,003; Yomiwato, 7133.

the community, either the market demand did not warrant an increase in hunting effort and/or the hunters could pass their time more profitably engaged in other activities. It is reasonable to believe, however, that if the local market demand for meat increases sufficiently, the Piro would increase the time they devote to hunting (see Hames, 1992 for a discussion of time allocation theory).

The difference in return rates combined with the similarity in the per capita harvest indicates that the Piro are devoting much less time to hunting than the Machiguenga. One of the incentives to adopt shotgun technology in this case is not more meat, but is the time the Piro hunters save. Shotguns free up time that otherwise would have to be devoted to hunting if bows were the only weapons available. While it has yet to be determined quantitatively, it is likely that this time is used by many Piro hunters to engage in other activities such as wage labour.

Another possibility is that, while Piro hunters may not harvest more meat per con- 
sumer than Machiguenga hunters, shotguns allow Piro hunters to support more consumers. This possibility becomes apparent if the factors that control population growth in the two populations are examined. The two communities differ in their access co western medicines. The Machiguenga rely almost totally on traditional healing practices, although they have benefited in the past from occasional immunizations (Kaplan et al., 1990). In contrast, the Piro have had western medicines available since at least the arrival of a government-sponsored school teacher in the early 1970s. In 1990 a medical clinic was built, which is occasionally stocked with antibiotics, antihelminths and rehydration mix, although the presence of a health-care worker is very sporadic. As a result of these differences, infant mortality is relatively high and population growth is slow for the Machiguenga, while for the Piro the reverse is true and population growth is quite rapid (see also Kroeger, 1982, Neel, 1982). The difference in survivorship in the two communities is notable. Infant mortality in the Machiguenga community is 53.9 per cent to age 15 years, compared with 28.5 per cent at Diamante. This translates into an annual growth rate of 1.2 per cent at Yomiwato and 4.7 per cent at Diamante (Kaplan et al., 1990). Thus, while the harvest per consumer at Diamante is essentially the same, shotguns may make it easier to support the increasing numbers of consumers at Diamante.

\section{Shotguns, human population size and sustainable hunting}

Recent work suggests that the area around the Piro village of Diamante may be suffering from over-exploitation and the near local extinction of a number of prey species, especially the large primates (black spider monkey Ateles paniscus and red howler monkey Alouatta seniculus) (Mitchell and Raez, 1990; Alvard, 1991, 1993a). The area around the Michuenga village of Yomiwato, while perhaps depleted to some degree compared with the unhunted areas around Cocha Cashu, has much higher densities of primates than the area around Diamante. This conclusion is supported by the higher rate of encounters with primate troops during hunts (see Alvard, 1993a) and primates accounting for a larger proportion of the Machiguenga's harvest (Figure 3).

How can the overhunting of primates by the Piro best be explained if shotguns are not being used to harvest more meat? One probable answer lies in the difference in the number of consumers in each community. Diamante has a population more than twice as large as the Yomiwato. Diamante, including its outlying settlements, has a population of 247 persons (213 consumers). Yomiwato has a population of 99 persons ( 85 consumers). Because more people require more food, the amount of meat taken will be proportional to the number of consumers at each village, all other things being equal. Although the amount of meat harvested per consumer was essentially equal for the two communities, because Diamante has a larger population, absolutely more meat and more animals were harvested there. The total annual harvest of each community was calculated by multiplying the per capita harvest by the total number of consumers. The estimated harvest for the entire population of Diamante is $53 \mathrm{~kg}$ per day, almost two-and-ahalf times the amount killed in Yomiwato where the harvest was $20.7 \mathrm{~kg}$ per day.

This brings us to the issue of culture change addressed in the introduction: what is it about western practices that cause the shift towards over-exploitation among indigenous people? One implication of the results presented in this paper is that it is not simply a change in hunting technology. The equivalent Piro and Machiguenga per capita harvest suggests that the difference in the total harvest is independent of technology and is simply a function of the consumer population size in each village. It follows that if the Machiguenga were allowed to use shotguns inside the park they would not deplete their prey populations, but only if their numbers are not allowed to increase. It is not technological limitations that work to limit exploitation, but rather factors that limit indigenous population growth and market participation. 


\section{Conclusion}

How do these results relate to the questions posed in the introduction concerning the role of indigenous peoples and conservation? The Machiguenga may hunt in a sustainable manner, but this does not demonstrate a concern or a commitment by the Yomiwato community to conserve. This observation merely represents an inability on the part of the Machiguenga to over-exploit, because their numbers are small. If the Machiguenga are not conservationists, the result that Diamante hunters do not harvest more meat per consumer, even though shotguns give them the ability, indicates that the Piro are not wanton despoilers of nature either. It is primarily the greater number of consumers at Diamante, and not shotguns, that is responsible for the depletion at that site. There is no evidence, however, that individual Piro hunters are restraining themselves even though as a group they are overhunting (Alvard, 1993b, 1994). Would it be expected that a hunter with a large and growing family kill fewer animals than could feed them? I am sure a Piro or Machiguenga hunter would answer no to this question.

\section{Acknowledgments}

This research was supported by the Charles Lindbergh Foundation, the Leakey Foundation, the Tinker Inter-American Research Foundation, the National Science Foundation (Grant BNS-8717886 to Hillard Kaplan) and the University of New Mexico.

\section{References}

Alcorn, J. 1993. Indigenous people and conservation. Conservation Biology, 7, 424-426.

Alvard, M. 1991. Prey encounters and distance from the village. Paper presented at the 90th meeting of the American Anthropological Association, Chicago.

Alvard, M. 1993a. Testing the ecologically noble savage hypothesis: conservation and subsistence hunting by the Piro of Amazonian Peru. PhD thesis, University of New Mexico, Albuquerque.

Alvard, M. 1993b. A test of the ecologically noble savage hypothesis: Interspecific prey choice by neotropical hunters. Human Ecology, 21, 355-387.
Alvard, M. 1994. Prey choice in a depleted area. Human Nature, 5, 127-154.

Alvard, M. and Kaplan, H. 1991. Procurement technology and prey mortality among indigenous neotropical hunters. In Human Predators and Prey Mortality (ed. Mary Stiner), pp. 79-104. Westview Press, Boulder.

Bunyard, P. 1989. Guardians of the Amazon. New Scientist, 17, 38-41.

Chagnon, N. 1993. Yanomamö: The Fierce People. Holt, Rinehart \& Winston, New York.

Clay, J. 1988. Indigenous Peoples and Tropical Forests: Models of Land Use and Management from Latin America. Cultural Survival, Inc., Cambridge.

Hames, R. 1979. A comparison of the efficiencies of the shotgun and the bow in neotropical forest hunting. Human Ecology, 7, 219-252.

Hames, R. 1987. Game conservation or efficient hunting? In The Question of the Commons (eds B. McCay and J. Acheson), pp. 97-102. University of Arizona Press, Tucson.

Hames, R. 1991. Wildlife conservation in tribal societies. In Biodiversity: Culture, Conservation and Ecodevelopment (eds M. Oldfield and J. Alcorn), pp. 172-199. Westview Press, Boulder.

Hames, R. 1992. Time allocation. In Evolutionary Ecology and Human Bahavior (eds E. A. Smith and B. Winterhalder), pp. 203-235. Aldine de Gruyter, New York.

Harner, M. 1968. Technological and social change among the Eastern Jivaro. XXXVII International Congress of Americanists, Buenos Aires, Argentina, pp. 363-388.

Kaplan, H., Alvard, M., Kopischke, K. and Phillips, T. 1990. Dieta, Salud, Demografia y technologia en Yomizato y Diamante. Primer informe del trabajo de campo (Junio 1988-Junio 1989) dentro y alrededor del Parque Nacional del Manú, Madre de Dios, Peru.

Kroeger, A. 1982. South American Indians between traditional and modern health services in rural Ecuador. Pan American Health Organization Bulletin, 16, 242-254.

Mitchell, C. and Raez, E. 1990. The Impact of Human Hunting on Primate and Game Bird Populations in the Manu Biosphere Reserve in Southeastern Peru. Report prepared for Wildlife Conservation International.

Mittermeier, R. 1987. Effects of hunting on rain forest primates. In Primate Conservation in the Tropical Rain Forest (eds C. Marsh and R. Mittermeier), pp. 109-148. Alan Liss, New York.

Neel, N. 1982. Infectious diseases among Amerindians. Medical Anthropology, Winter, 47-54.

Posey, D. 1985. Native and indigenous guidelines for new Amazonian development strategies: understanding biodiversity through ethnoecol- 
ogy. In Change in the Amazon (ed. J. Hemming), pp. 156-181. Manchester University Press, Manchester.

Rambo, A. 1978. Bows, blowpipes, and blunderbusses: ecological implications of weapon change among Malaysian Negritos. Malayan Nature Journal, 32, 209-216.

Redford, K. 1991. The ecologically noble savage. Orion, 9, 24-29.

Redford, K. and Stearman, A. 1993. Forest-dwelling native Amazonians and the conservation of biodiversity: Interests in common or in collision? Conservation Biology, 7, 248-255.

Redford, K. and Robinson, J. 1987. The game of choice: patterns of Indian and Colonist hunting in the neotropics. American Anthropologist, 89, 650-667.

Terborgh, J. 1983. Five New World Primates. Princeton University Press, Princeton.

Vickers, W. 1976. Cultural adaptations to Amazonian habitats: the Siona-Secoya of eastern Ecuador. PhD thesis, University of Florida, Gainesville.

Yost, J. and Kelly, P. 1983. Shotguns, blowguns, and spears: The analysis of technological efficiency. In Adaptive Responses of Native Amazonians (eds R. Hames and W. Vickers), pp. 189-224. Academic Press, New York.

Michael Alvard, Department of Anthropology, SUNY, 380 MFAC, Buffalo, NY 14261, USA. 